\title{
Selection of non-P-glycoprotein mediated high-level etoposide resistant cell lines by adriamycin with $\mathbf{P}$-gp inhibitors
}

\author{
STEVEN ADES ${ }^{1,2}$, LORI F. MAXFIELD ${ }^{1}$, CHRISTOPHER J. GOULD ${ }^{1,3}$, \\ GRAHAM K. JONES ${ }^{1,4}$ and STUART B. LEVY ${ }^{1}$ \\ ${ }^{1}$ Center for Adaptation Genetics and Drug Resistance, Department of Molecular Biology and Microbiology, \\ and Department of Medicine, Tufts University School of Medicine, Boston, MA 02111, USA
}

Received September 27, 2005; Accepted November 14, 2005

\begin{abstract}
In murine erythroleukemia (MEL) A20 cells (grown in $20 \mathrm{ng} / \mathrm{ml}$ adriamycin), mutation(s) producing 10-fold adriamycin (doxorubicin) resistance emerged via an unknown mechanism. Exposure of A20 cells to further stepwise increasing concentrations of ADR in combination with MDR modulators (PSC833 and verapamil) aimed to amplify the undetermined A20 mechanism while controlling P-glycoprotein (P-gp) overexpression. The growth of the derived cell lines A30P, A40P and A60P (grown in 30, 40 and $60 \mathrm{ng} / \mathrm{ml}$ ADR with PSC833 and verapamil) was initially slow, but eventually reached near WT rates. The new cell lines A30P and A40P were only 1.3- and 1.6-fold more resistant to adriamycin than PC4 A20. Resistance to vincristine was unchanged, but resistance to etoposide (VP-16) was 3.7-fold higher in A40P than A20 (itself 97-fold higher than wild-type). Expression of $m d r 3$ and $m r p$ mRNA tested by RT-PCR showed no increase. Daunorubicin and etoposide accumulation was not different among the cell lines, and no changes were detected in the number of daunorubicin fluorescent lysosomes. In comparison to WT, reduced topoisomerase II $\alpha$ (EC 5.99.1.3) activity (20\%) and protein expression (80\%) was similar to the parental A20
\end{abstract}

Correspondence to: Dr Stuart B. Levy, Center for Adaptation Genetics and Drug Resistance, Department of Molecular Biology and Microbiology, Tufts University School of Medicine, 136 Harrison Ave., Boston, MA 02111, USA

E-mail: stuart.levy@tufts.edu.

Present addresses: ${ }^{2}$ McGill University Health Center, Montreal General Hospital, 1650 Cedar Ave, Suite A7-130, Montreal, Quebec H3G 1A4, Canada; ${ }^{3}$ Brandeis University, Department of Biochemistry, MS009, Waltham, MA 02454-9110, USA; ${ }^{4}$ Paratek Pharmaceuticals, Inc., 75 Kneeland Street, Boston, MA 02111, USA

Abbreviations: MEL, murine erythroleukemia; P-gp, P-glycoprotein; MDR, multidrug resistance; ADR, adriamycin; wt, wild-type; MRP, multidrug resistance protein; RT-PCR, reverse transcriptasepolymerase chain reaction; glc, glucose; MTT, 3-(4,5-dimethylthiazol-2-yl)-2,5-diphenyltetrazolium bromide; DNR, daunorubicin

Key words: multidrug resistance, P-glycoprotein, topoisomerase, erythroleukemia cell, adriamycin, drug transport cells. No mutations in the coding sequence of topoisomerase II $\alpha$ could be located to account for the high etoposide resistance levels. The inhibitor combination of verapamil and PSC833 prevented the emergence of transporter mediated MDR, but not ADR selection of cell lines highly resistant to etoposide.

\section{Introduction}

The development of drug resistance in cancer cells is a major problem in clinical oncology. Although observations of a large number of cell lines indicate that resistance emerges in steps from low, through intermediate, to high levels, the genetic and/or biochemical basis for early drug resistance is unclear. The in vitro multidrug resistance (MDR) phenotype, a late form of acquired resistance, is characterized by reduced susceptibility to structurally dissimilar antineoplastic agents including anthracyclines, Vinca alkaloids and epipodophyllotoxins (reviewed in refs.1 and 2). The predominant mechanism of anthracycline induced cellular MDR is activation of efflux proteins P-glycoprotein (P-gp, MDR1) and multidrug resistance protein (MRP), which results in the transport of xenobiotics to the outside of the cell. However, resistance to anthracyclines can also be attributed to topoisomerase II $\alpha$ (EC 5.99.1.3) alterations (3), subcellular redistribution into lysosomes $(4,5)$, enhanced drug detoxification $(6,7)$ and abrogation of apoptosis $(8)$.

There has been relatively less effort to identify low-level mechanisms of resistance in cancer cells prior to the acquisition of high-level mechanisms, such as the P-gp pump $(9,10)$. Low to intermediate resistance mechanisms may be more clinically relevant than those of highly resistant cell lines, as only 5fold resistance may be all that is necessary to overcome the effects of cytotoxic agents in vivo. Further, because of the toxicity of many chemotherapy drugs, there are restrictions on higher dosing regimens, limiting the concentration of drug acting upon cancerous tissues.

Previously, our laboratory generated and described a series of MDR murine erythroleukemia (MEL-PC4) cell lines selected by exposure to ADR in sequentially increasing amounts. Resistance emerged in a stepwise fashion (11) from low-level resistance to high-level (P-gp mediated) resistance to multiple classes of drugs (12). The initial adaptation of PC4 cells to increasing doses of ADR $(5 \rightarrow 10 \rightarrow 20 \mathrm{ng} / \mathrm{ml})$ was associated with reduced topoisomerase II $\alpha$ and II $\beta$ enzyme levels (13), and increased c-Fos expression (14). Only in A40 cells (grown in 
$40 \mathrm{ng} / \mathrm{ml} \mathrm{ADR}$ ) was P-gp expression up-regulated. The lowlevel mutation(s) associated with A20 cells (derived in $20 \mathrm{ng} /$ $\mathrm{ml} \mathrm{ADR}$ ) are, as yet, unknown. The resistance phenotype in A20 cells is not modulated by MDR inhibitors, nor is it accompanied by alterations in glutathione/glutathione S-transferase levels, internal $\mathrm{pH}$, or overexpression of $m d r 3$ (murine homologue of MDR1), mrp, or $m v p$ (murine homologue of LRP) genes (13).

We describe the development and characterization of new cell lines selected by ADR, along with P-gp inhibitors, designed to amplify the unknown mechanism for the A20 cell line. The new cell lines showed a small increase in ADR resistance but exhibited high levels of etoposide resistance without the up-regulation of $\mathrm{ABC}$ type efflux pumps.

\section{Materials and methods}

Materials. All drugs were purchased from Sigma-Aldrich (Milwaukee, WI, USA) or Invitrogen (Carlsbad, CA, USA). PSC833 (Valspodar) was obtained from Novartis Pharma AG (Basel, Switzerland). SYBR Green PCR Master Mix and Multiscribe Reverse Transcriptase were purchased from Applied Biosystems (Foster City, CA, USA).

Cell viability assay. Cell viability was measured by the MTT assay after $48 \mathrm{~h}$, as described previously (15). Ninety-six well tissue culture plates were read using a Spectramax 250 plate spectrophotometer (Molecular Devices, Sunnyvale, CA, USA). The $\mathrm{IC}_{50}$ is the concentration of drug that results in a $50 \%$ decrease in cell viability. Assays were typically performed after 25 and 30 passages in culture conditions.

Growth of cell lines. The original selected PC4 series of drug resistant cell lines were named to reflect the highest concentration of ADR in which they were selected, i.e. PC4 A20 were selected by $20 \mathrm{ng} / \mathrm{ml}$ ADR (13). Cells were cultured in Basal Medium Eagle (BME), 10\% FBS, L-glutamine and $100 \mathrm{ng} / \mathrm{ml}$ gentamicin. Cell counts were made using a model ZBI Coulter Counter.

The A30P, A40P and A60P cell lines were derived by exposure of A20 cells to 30, 40 and $60 \mathrm{ng} / \mathrm{ml}$ of ADR, respectively, in the presence of PSC833 $0.2 \mu \mathrm{g} / \mathrm{ml}$ and verapamil $1 \mu \mathrm{M}$. A new control cell line (A30co) was derived for the present study by repeated passage of A20 cells in the presence of ADR $(30 \mathrm{ng} / \mathrm{ml})$ without any inhibitors. Inhibitor concentrations were chosen so as not to adversely affect cell growth, but to inhibit pump mediated ADR resistance by $>90 \%$ in P-gp overexpressing PC4 A80 cells.

Cell line growth under adriamycin selection in the presence of efflux protein inhibitors. To inhibit expression of ABC type efflux proteins, we used various combinations of PSC833 and verapamil. PSC833 is a cyclosporin A derivative which exerts a higher MDR reversal activity and lacks the toxic or immunosuppressive side effects of cyclosporin A (16-19). Cell viability assays were performed over a range of inhibitor concentrations to determine the maximum concentration that supported $90 \%$ cell growth compared to control cultures (data not shown). Subsequent assays then used this concentration of PSC833 in combination with ADR in the highly P-gp expressing A80 cell line to determine if the concentration was sufficient to reduce the $\mathrm{IC}_{50}$ of $\mathrm{ADR}$ to that of the $\mathrm{A} 20$ cell line. The fold resistance to ADR of the A80 cell line decreased from 71.1 to 9.7 and 8.3 in the presence of $0.2 \mu \mathrm{g} /$ $\mathrm{ml}$ PSC833. These values matched the resistance of the A20 cells, determined both in our hands (10.0 2.3 , data not shown), and in previous published work [17-fold resistance; (11)]. Thus, the concentration of inhibitors used to develop these cell lines was sufficient to inhibit the efflux proteins.

Cell lines meant to amplify the uncharacterized mechanism present in A20 were initiated by exposure to increasingly higher concentrations of ADR in the presence of MDR1 inhibitors as described in the methods. On exposure to $30 \mathrm{ng} /$ $\mathrm{ml}$ ADR in the presence of inhibitors, growth was initially slow, with doubling times of 17.1 (A30co) and 22.1 (A30P) h, compared with a doubling time of $10.5 \mathrm{~h}$ for A20. The experimental cell lines stabilized at doubling times of $14.3 \mathrm{~h}$ (A30P) passage 22; $\mathrm{A} 40 \mathrm{P}$ and $\mathrm{A} 60 \mathrm{P}$ showed growth rates similar to A30P.

Fluorescence RT-PCR. Quantitative one-step fluorescent RT-PCR was performed using an ABI PRISM 5700 Sequence Detector. Total cellular RNA was extracted using Trizol Reagent (GibcoBRL, Grand Island, NY, USA), followed by DNAse treatment, phenol-chloroform extraction, and ethanol precipitation. A non-specific DNA-intercalating dye contained within the SYBR ${ }^{\circledR}$ Green Master Mix (Applied Biosystems, Foster City, CA, USA) and Multiscribe ${ }^{\mathrm{TM}}$ Reverse Transcriptase were used in RT-PCR experiments according to product specifications. The total volume of a one-step reaction was $25 \mu \mathrm{l}$ including $12.5 \mu \mathrm{l}$ of $2 \mathrm{X}$ Master Mix, $5 \mu \mathrm{l}$ primers, $5 \mu 1 \mathrm{tRNA} /$ water $(1 \mathrm{mg} / \mathrm{ml})$, and $2.5 \mu \mathrm{l}$ of RNA template $(0.2 \mathrm{mg} / \mathrm{ml})$. Thermocycling parameters were $30 \mathrm{~min}$ at $48^{\circ} \mathrm{C}$ for reverse transcription (RT), $10 \mathrm{~min}$ at $95^{\circ} \mathrm{C}$ for RT inactivation and DNA polymerase activation, $94^{\circ} \mathrm{C}$ denaturation (30 sec), $53^{\circ} \mathrm{C}$ annealing $(1 \mathrm{~min})$ and $72^{\circ} \mathrm{C}$ synthesis $(1 \mathrm{~min})$. Product dissociation curves were analyzed to ensure appropriate product size and absence of template contamination in controls. Relative standard curves were generated using ampliconcontaining plasmids to enable comparison of mRNA expression among cell lines. All samples were performed in triplicate over a minimum of 2 separate experiments.

Primers used were $m d r 1 / m d r 3$ : forward, AAGGGCCTCA ATCTGAAGGT (nucleotides 1355-1374) and reverse, CCT GACTCACCACACCAATG (nucleotides 1550-1531), product size 196 bp; murine mrpl: forward, ATGGCCATGAAGAC CAAGAC (nucleotides 1450-1469) and reverse, CTGCCAG GTAGGCAGATTTC (nucleotides 1642-1623), product size 193 bp; $\beta$-actin: forward, TTGACATCCGTAAAGACC (nucleotides 782-799) and reverse, CTTGCTGATCCACAT CTG (nucleotides 999-982), product size 217 bp.

Fluorescence microscopy. Cells $\left(1 \times 10^{6} / \mathrm{ml}\right)$ were incubated in BME containing $500 \mathrm{ng} / \mathrm{ml}$ daunorubicin (DNR) for $1 \mathrm{~h}$. Subsequently, cells were washed with ice-cold phosphatebuffered saline (PBS), resuspended in PBS containing $5 \mathrm{mM}$ glucose, and kept on ice until viewing with a Leica TCS SP2 confocal microscope or an upright Leica DMRXE microscope using a x63 (1.32 NA) apochromatic lens. The DNR was excited at the $488 \mathrm{~nm}$ wavelength with an argon laser. 
Table I. Cell viability assay results in transport protein inhibitor selected MEL cell lines. ${ }^{a}$

\begin{tabular}{|c|c|c|c|c|c|c|c|}
\hline \multirow[b]{2}{*}{ Drug } & \multicolumn{7}{|c|}{ Cell line $\mathrm{e}^{\mathrm{a}}$} \\
\hline & $\mathrm{A} 20^{\mathrm{c}}$ & $\mathrm{A} 40^{\mathrm{c}}$ & $\mathrm{A} 80^{\mathrm{c}}$ & $\mathrm{A} 30 \mathrm{co}^{\mathrm{d}}$ & $\mathrm{A} 30 \mathrm{P}^{\mathrm{d}}$ & $\mathrm{A} 40 \mathrm{P}^{\mathrm{d}}$ & $\mathrm{A} 60 \mathrm{P}^{\mathrm{C}}$ \\
\hline $\mathrm{ADR}^{\mathrm{b}}$ & $10.0 \pm 2.3$ & $19.2 \pm 4.5$ & $61.5 \pm 17.1$ & $58.2 \pm 19.6$ & $13.3 \pm 3.2$ & $15.5 \pm 0.1$ & - \\
\hline $\mathrm{VCR}^{\mathrm{b}}$ & $1.6 \pm 0.5$ & $3.5 \pm 1.1$ & $11.0 \pm 6.5$ & $12.3 \pm 0.6$ & $2.3 \pm 0.6$ & $2.2 \pm 0.4$ & - \\
\hline VP-16 & $97.0 \pm 9.0$ & $\mathrm{nt}^{\mathrm{e}}$ & $209.0 \pm 26.0$ & $\mathrm{nt}$ & $\mathrm{nt}$ & $371.0 \pm 9.0$ & $\mathrm{nt}$ \\
\hline
\end{tabular}

${ }^{a}$ Measured by MTT assay; experiment performed minimum of 3 times. Values are reported as fold resistance compared to PC4-WT calibrator. Baseline $\mathrm{IC}_{50}$ concentrations for WT are 10.8 $\pm 3.2,1.3 \pm 0.4$ and $35 \pm 5.0 \mathrm{ng} / \mathrm{ml}$ for ADR, VCR and VP-16, respectively. ${ }^{\mathrm{b}} \mathrm{ADR}$, adriamycin; VCR, vincristine, VP-16, etoposide. ${ }^{\mathrm{c}}$ Selected in adriamycin at 20,40 and $80 \mathrm{ng} / \mathrm{ml}$ (reviewed in ref. 11). ${ }^{\mathrm{d} C e l l ~ l i n e s ~ s e l e c t e d ~ i n ~ A D R ~} 30 \mathrm{or} 40 \mathrm{ng} / \mathrm{ml}$ with (P) or without (co) efflux protein inhibitors (see text). ${ }^{\mathrm{e}} \mathrm{nt}$, not tested.

Emission was read at $600 \mathrm{~nm}$. Lysosomes were counted in at least 10 individual cells and averaged.

Assay of topoisomerase II activity. Cells were lysed and topoisomerase containing extracts were prepared as described previously (13). Using a topoisomerase II assay kit from TopoGEN (Columbus, OH, USA), the ability of nuclear extracts to decatenate kinetoplast DNA was measured. Electrophoretic analysis of kDNA products was performed and bands were quantitated using NIH Image software (NIH, Fredrick, MD, USA).

Western blot analysis. Proteins were prepared from nuclear extracts following the protocol supplied by TopoGEN. Protein content was standardized by Bradford Assay, and $8 \mu \mathrm{g}$ of total protein was separated by SDS-PAGE and electroblotted onto a PVDF membrane (Perkin-Elmer, Boston, MA, USA) in a $25 \mathrm{mM}$ Tris, $192 \mathrm{mM}$ glycine and $20 \%$ methanol buffer. Blots were probed with a topoisomerase II antibody obtained from TopoGEN and visualized with Western Blot Chemiluminescent Reagent Plus (Perkin-Elmer) using Kodak Biomax MR film (Rochester, NY, USA). Images were quantitated using NIH Image.

Sequence analysis of topoisomerase IIa. Sequence analysis of the topoisomerase II $\alpha$ gene (GenBank Accession no. NM_011623) was performed on each of the cell lines indicated to determine the presence of any mutations. Total RNA was prepared using a Qiagen RNeasy kit, and one tenth of oligo (dT) primed reverse transcription reactions derived from each cell line were added to other PCR components under conditions identical to those reported previously (20). Samples were then sent for sequence analysis to the Tufts University Core Facility. Primers were TopoIIaForl: ATGGAGTTGTCACC GCT forward, and reverse TopoIIaRev1: TCAGAAGAGG TCGTCAT for PCR reactions and initial sequencing. For full sequencing, TopoIIaseq2: GTGGGAAGTGTGCTTAACA, TopoIIaseq3: TTATGGGAAGATCATGATTA and TopoII aseq4: GCCCTTTGGCTCGGTTGTT were used.

Etoposide accumulation assay. The drug accumulation assay was performed as reported previously (13). Briefly, cells were incubated at $1 \times 10^{7} / \mathrm{ml}$ in PBS containing $5 \mathrm{mM}$ glucose, with $4 \mu \mathrm{M}\left[{ }^{3} \mathrm{H}\right]$-labeled etoposide (specific activity $654 \mathrm{mCi} / \mathrm{mmol}$ ) (Moravek Biochemicals, Brea, CA, USA) for $1 \mathrm{~h}$ at $37^{\circ} \mathrm{C}$, with shaking. A $200 \mu 1$ sample was layered over a $200 \mu 1$ mixture of silicone oil ( $\mathrm{d}=1.04 \mathrm{~g} / \mathrm{ml}$ ) (Nye Lubricants, Inc., New Bedford, MA, USA) over $20 \mu \mathrm{l}$ of concentrated formic acid in a microfuge tube. The tube was centrifuged in a tabletop microcentrifuge at maximum for $30 \mathrm{sec}$ and then frozen at $-80^{\circ} \mathrm{C}$. The frozen formic acid layer containing the cell pellet was cut-off and counted by liquid scintillation. A zero control was performed by incubation of WT cells in PBS containing $5 \mathrm{mM}$ glucose without drug, followed by $5 \mathrm{~min}$ incubation on ice. Labeled etoposide was then added and cells were treated as above, and results subtracted from all samples. Experiments were repeated a minimum of three times.

Statistical analyses. Fold resistances were determined by standard bioassay methods by calculating average $\mathrm{IC}_{50} \mathrm{~s}$ and corresponding standard deviations. The calibrators for these ratios were the WT or A20 cell lines. The confidence intervals for the lysosome counts were calculated using two-sided $95 \%$ t-values taken from a Student's t-test distribution.

\section{Results}

Determination of multidrug resistance phenotype in cell lines grown in the presence of ADR and efflux protein inhibitors. Cell viability (MTT) assays were performed on the newlyderived cell lines to determine the degree of resistance to ADR, vincristine, and etoposide (Table I). Using the WT cell line as a calibrator, results showed an incremental increase in resistance to ADR from 10 in A20 to 13.3- and 15.5-foldresistance for $\mathrm{A} 30 \mathrm{P}$ and $\mathrm{A} 40 \mathrm{P}$ cells, respectively. Resistance profiles of the MDR expressing A80 cell line and the newly derived control line A30co were elevated and comparable to previous work (11-13). The data for vincristine susceptibility were similar to A20 cell lines. However, higher etoposide resistance was found in the A20 derived cell lines as compared to A20 (Table I).

Lack of expression of mdr3 and mrp genes in cell lines developed in the presence of efflux protein inhibitors. 
Table II. Fluorescence RT-PCR results for $m d r$ and $m r p$ mRNA expression in single drug and transport protein inhibitor selected MEL cell lines. ${ }^{a}$

\begin{tabular}{lrrrrrrr}
\hline & \multicolumn{7}{c}{ Cell line $^{\mathrm{a}}$} \\
\cline { 2 - 7 } Gene $^{\mathrm{b}}$ & $\mathrm{A} 20^{\mathrm{d}}$ & $\mathrm{A} 40^{\mathrm{d}}$ & $\mathrm{A} 80^{\mathrm{d}}$ & $\mathrm{V} 40^{\mathrm{c}}$ & $\mathrm{A} 30 \mathrm{co}^{\mathrm{e}}$ & $\mathrm{A} 30 \mathrm{P}^{\mathrm{e}}$ & $\mathrm{A} 40 \mathrm{P}^{\mathrm{e}}$ \\
\hline$m d r$ & $1.4 \pm 0.1$ & $1.5 \pm 0.4$ & $17.7 \pm 8.6$ & $\mathrm{nt}^{\mathrm{f}}$ & $4.3 \pm 1.3$ & $1.2 \pm 0.2$ & $1.3 \pm 0.5$ \\
$m r p$ & $3.1 \pm 1.0$ & $1.7 \pm 0.6$ & $1.2 \pm 0.1$ & $43.6 \pm 10.1$ & $2.1 \pm 0.4$ & $3.2 \pm 1.2$ & $3.6 \pm 2.5$ \\
\hline
\end{tabular}

${ }^{\text {a }}$ Values are reported as fold increase compared to PC4-WT calibrator. ${ }^{\mathrm{b}} m d r, 200 \mathrm{bp}$ amplicon found in both $m d r 1$ and $m d r 3$ murine isoforms of the multidrug resistance gene; $m r p$, multidrug resistance-related protein. ${ }^{~}$ PC4-V40 was the positive control cell line used in the $m r p$ RT-PCR. Selected previously with $40 \mathrm{ng} / \mathrm{ml}$ vincristine (13). ${ }^{\mathrm{d}}$ Selected in adriamycin at 20, 40 and $80 \mathrm{ng} / \mathrm{ml}(11)$. ${ }^{\mathrm{e}}$ Cell lines selected in Adriamycin 30 or $40 \mathrm{ng} / \mathrm{ml}$ with (P) or without (co) efflux protein inhibitors (see text). ${ }^{\mathrm{f}} \mathrm{nt}$, not tested.

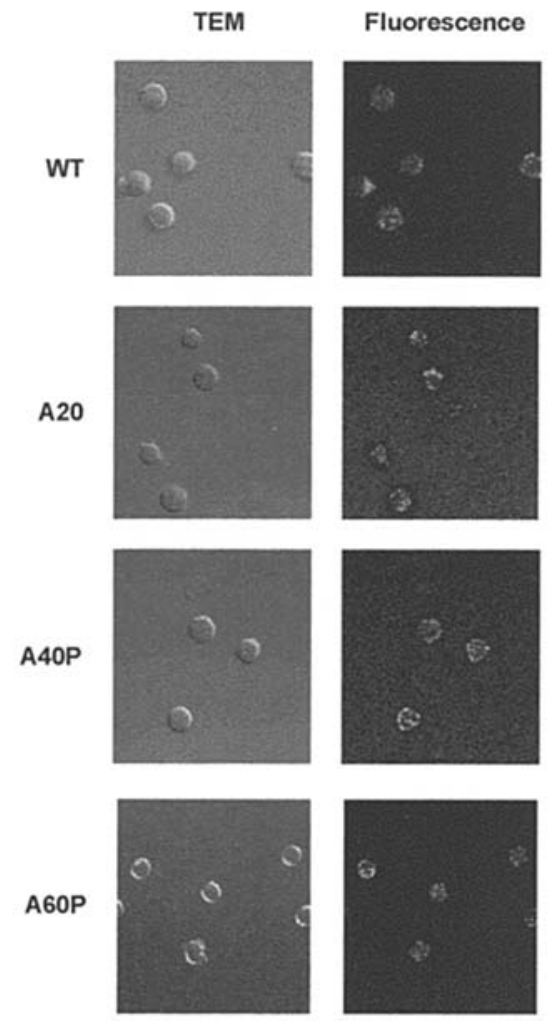

Figure 1. Daunorubicin (DNR) subcellular distribution in PC4 cells. Cells were incubated for $1 \mathrm{~h}$ with $500 \mathrm{ng} / \mathrm{ml}$ DNR, washed and resuspended in PBS before viewing at $63 \mathrm{X}$ with a Leica TCS SP2 confocal microscope. DNR was excited at $420 \mathrm{~nm}$ with emission of $600 \mathrm{~nm}$. The number of acidic vesicles in each cell line was: WT, 17 \pm 6.2 ; A30co, none detected; A20, 21 \pm 3.7 ; A40P, 18.8 \pm 4 .6. Experiments were repeated a minimum of three times.

Quantitative fluorescent RT-PCR was used to ensure that $m d r 1, m d r 2$ and $m d r 3$ (the murine genes homologous to human $m d r l)$ and the $m r p$ gene were not overexpressed. No increase in $m d r 3$ or $m r p$ expression was seen in A30P or A40P cells, while A30co cells showed a 4-fold increase in mdr3 expression, compared to WT (Table II). PC4 V40, a cell line obtained through exposure of WT cells to $40 \mathrm{ng} / \mathrm{ml}$ vincristine serves as a positive control for the $m r p$ expression RT-PCR assays (21). As expected, there was an 18-fold increase in $m d r 3$ expression in A80 cells, serving as a positive control for $m d r 3$.

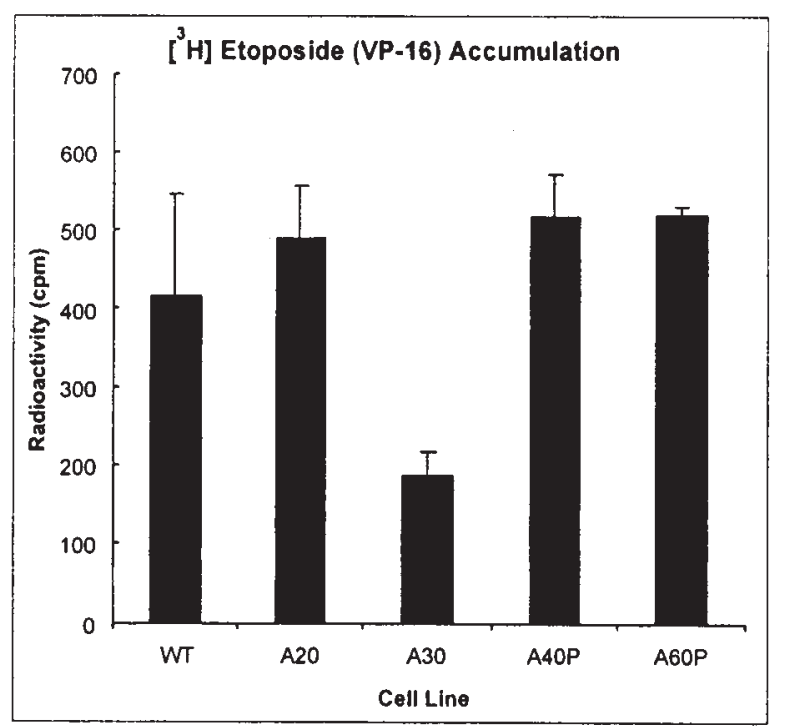

Figure 2. Accumulation of $\left[{ }^{3} \mathrm{H}\right]$-etoposide into MEL-PC4 cells. Cells were incubated with $4 \mu \mathrm{M}\left[{ }^{3} \mathrm{H}\right]$-etoposide for $1 \mathrm{~h}$ at $37^{\circ} \mathrm{C}$. A $200 \mu 1$ sample was layered over silicone oil over concentrated formic acid. The tube was centrifuged and then frozen at $-80^{\circ} \mathrm{C}$. The frozen formic acid layer containing the cell pellet was cut-off and counted by liquid scintillation. Experiments were repeated a minimum of three times.

Daunorubicin and etoposide accumulation in cell lines developed in the presence of inhibitors. The subcellular daunorubicin distribution within selected cell lines was examined by confocal microscopy. Daunorubicin accumulation into cytoplasmic vesicles detected by fluorometric methods $(5,11)$ was observed in all cell lines, except for the control cell line A30co (data not shown). This finding indicated that the efflux pump was up-regulated and functional in the control cells under experimental conditions. No changes were detected in the number of fluorescent lysosomes (Fig. 1), confirming that the observed increase in resistance in the selected cell lines was not due to an altered intracellular distribution pattern of DNR.

We measured the accumulation values of $\left[{ }^{3} \mathrm{H}\right]$-labeled VP-16 for the drug and inhibitor selected cell lines (Fig. 2). The results indicated no change in cellular uptake or efflux for the ADR and PSC833 + verapamil selected cells. There- 
Table III. Topoisomerase II activity and expression in selected MEL cell lines. ${ }^{a}$

\begin{tabular}{lcc}
\hline & \multicolumn{2}{c}{ topo II } \\
\cline { 2 - 3 } Cell line & Activity (\%) & Protein (\%) \\
\hline PC4-WT & 100 & 100 \\
PC4-A20 & $29 \pm 14$ & $84 \pm 8$ \\
PC4-A30C & $27 \pm 14$ & $91 \pm 9$ \\
PC4-A40PSC & $29 \pm 15$ & $82 \pm 3$ \\
\hline
\end{tabular}

${ }^{a}$ Activity measured by kinetoplast decatenation assay and protein expression by Western blot analysis (see text).

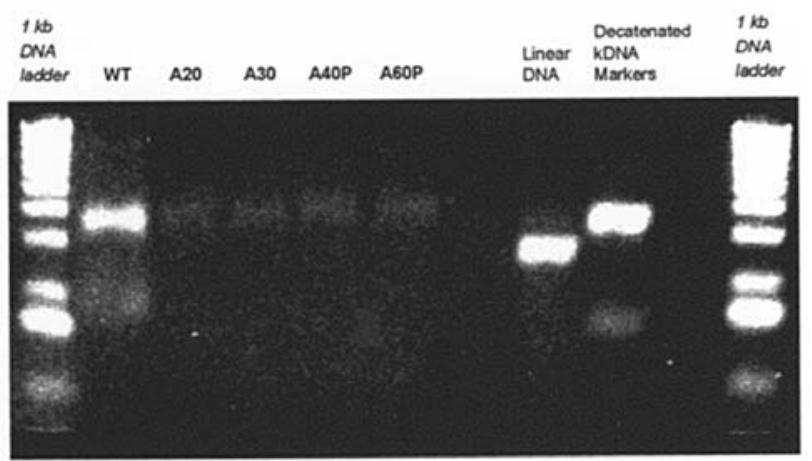

Figure 3. Topoisomerase II $\alpha$ activity present in nuclear extracts of cell lines as measured by kDNA decatenation. Nuclear extracts were incubated with kinetoplast DNA at $37^{\circ} \mathrm{C}$ for $1 \mathrm{~h}$. The reactions were then separated by electrophoresis at $100 \mathrm{~V}$ for $1 \mathrm{~h}$. Nuclear extracts were prepared as described in Materials and methods.

fore, there was no evidence for up-regulation of another effluxbased mechanism as a determinant of resistance in these cells.

Topoisomerase II activity, expression and sequence. We quantitated both topoisomerase II $\alpha$ activity and protein level, measured by the ability of cell extracts to decatenate kinetoplast DNA, and Western blot analysis. Like PC4 A20, topoisomerase II $\alpha$ protein content was decreased to approximately $80 \%$ of the WT cell amounts (Table III) in the selected cell lines. Activity levels of the cellular extracts were also like A20, namely, approximately $20 \%$ of control levels (Fig. 3). A mutational analysis of the $\alpha$ isoform was initiated to determine if the enzyme-drug interaction between etoposide and topoisomerase II was specifically modulated. No mutational differences from WT cells were found in any part of the coding sequence of the topoisomerase II $\alpha$ protein of PC4 A20 or any of the drug and inhibitor selected cell lines (data not shown).

\section{Discussion}

In previous studies, a pattern of changes was detected in the PC4 series of murine erythroleukemia cell lines exposed to incrementally increased concentrations $(5-80 \mathrm{ng} / \mathrm{ml})$ of ADR (doxorubicin) (11). The earliest changes included reductions in topoisomerase II activity to approximately $40 \%$ of baseline, a corresponding decrease in topoisomerase II $\alpha$ protein, and decreases in both topoisomerase II $\alpha$ and topoisomerase IIß mRNA levels (13). Furthermore, A40 (grown in $40 \mathrm{ng} / \mathrm{ml}$ adriamycin) was the earliest cell line to show overexpression of $m d r 3$ compared to the WT cell line, as detected by RT-PCR. There was no detectable expression of $m d r 3$ in A20 cells, but it was clear to investigators, as evidenced by $m d r 3$ expression levels in A40 cells, that further exposure to higher concentrations of adriamycin would result in the establishment of P-gp mediated MDR. The $m d r 3$ gene was the only isoform of murine P-gp induced in this series.

In order to investigate the underlying mechanism(s) of resistance contributing to the A20 phenotype, we attempted to amplify the ADR resistance of this cell line in the presence of combinations of transporter protein inhibitors, namely PSC833, and verapamil, which have been shown to inhibit activity of key ABC transporters $(13,22)$. In our study, the inhibitor combination prevented up-regulation of $m d r 3$ or mrp mRNA expression, and resulted in only a small increase in ADR resistance but a large increase in etoposide resistance. The latter was not associated with a change in daunorubicin or etoposide intracellular accumulation. These data point out the usefulness of PSC833 as an inhibitor of increased expression of efflux pump proteins.

Most studies have focused on the use of inhibitors in cell lines that already express P-gp (16-19). However, PSC833 $(3,23,24)$, or verapamil $(25)$, have previously been used to inhibit the emergence of MDR, with varying success. In one report, following selection with PSC833 and ADR in MES-SA human sarcoma cells, a mutant P-gp variant with decreased affinity for PSC833 and Vinca alkaloids was derived (24). In another study, after a brief 3-week exposure to the same drugs, the only alterations detected were a decrease in topoisomerase II $\alpha$ mRNA and protein, with an associated drop in catalytic activity (3). Other investigators found that a combination of both PSC833 and CSA was required to prevent MDR1 up-regulation caused by exposure to the drug epirubicin (23). A third group successfully used verapamil and ADR co-selection to derive drug resistant human multiple myeloma cells with decreased topoisomerase II levels and activity, and no P-gp overexpression (25). None of these mechanisms is likely to account for the high etoposide specific phenotype of our derived cell lines.

The resistance phenotype of A20 cells includes a decrease in both topoisomerase II $\alpha$ and II $\beta$ protein and activity. This type of multidrug resistance, associated primarily with altered topoisomerase II $\alpha$, has been reported in cases where a single topoisomerase II interacting drug was used to select the resistance phenotype $(20,26-28)$. A recent study of the multidrug-resistant K562 human leukemia cell line after exposure to the anthracycline derivative MX2 reported reduced topoisomerase II $\alpha$ protein levels and catalytic activity. Interestingly, resistance was attributed to reduced topoisomerase II $\alpha$ gene expression and increased methylation of the gene which could be overcome in the presence of a demethylating agent (29). A previous study of the CCRF-CEM cell line, and two teniposide (VM-26) resistant sublines, showed that topoisomerase II $\alpha$ in nuclear extracts from resistant cells 
required a higher concentration of ATP than sensitive cell extracts to achieve equivalent activity in a DNA unknotting assay (20). This study confirmed through DNA sequencing the presence of a $\mathrm{G}$ to $\mathrm{A}$ base change and corresponding amino acid substitution at a critical ATP interaction site. A number of other resistance causing mutations in the sequence of topoisomerase II $\alpha$ have been reported in the literature $(27,30$ 32). Alterations in the phosphorylation status of the topoisomerase II $\alpha$ enzyme have been implicated as causing a resistance phenotype (33). Changes in topoisomerase II can have other effects in the cell that can then lead to chemoresistance. For example, altered topoisomerase II function can lead to an increase in DNA damage, which is a critical signal for transcription factor NF- $\mathrm{\kappa B}$ activation. Altered $\mathrm{NF}-\kappa \mathrm{B}$ activation has been shown to contribute to anthracycline drug resistance in a human ovarian carcinoma cell line (34), and gemcitabine resistance in pancreatic carcinoma cell lines (35). This and other anti-apoptotic proteins such as IAPs and BCL-2 have been implicated in cellular resistance to cytotoxic agents $(36,37)$.

In summary, our results support a growing body of evidence showing that treatment with multidrug resistance modulators, such as cyclosporin A, PSC833 and verapamil, together with multidrug resistance cytotoxins, can suppress the emergence of $\mathrm{ABC}$ transporter mediated resistance. Our results also indicate that even when the efflux protein pump is effectively inhibited, an extremely high level of resistance can emerge, as observed in the A40P cell line that has an etoposide resistance level 371-fold higher than that of the WT cell line. It should be noted that a topoisomerase II enzyme alteration contributes, at least in part, to the resistant phenotype observed in the A20 cells. Possible explanations are an increase or decrease in phosphorylation of the enzyme, or a redistribution of the drug to outside the nucleus into the cytoplasmic compartment $(33,38)$. However, these changes would not account for an etoposide specific resistance phenotype. Thus, while resistance to etoposide is 3-fold greater in A40P than A20, topoisomerase II $\alpha$ activity and topoisomerase II $\alpha$ protein levels are similar among all of the A20 derived cell lines, and reduced as compared to wild-type. Furthermore, in this cell line, there was no evidence of a change in subcellular redistribution of daunorubicin into increasing numbers of lysosomes, and prior work from this group showed no changes in glutathione levels, cellular $\mathrm{pH}$, or expression of the major vault protein (13) in A20 cells. These findings suggest that at least one other mechanism may be accounting for the increased resistance to etoposide in A40P and A60P cells. Given that multiple apoptotic mechanisms are at play which may be distinct for different cytotoxic agents, drugspecific resistance to programmed cell death may be contributing to the phenotype of the new cell lines. Future work will focus on microarray transcription analysis to look at differential gene expression across this new series of cell lines.

\section{Acknowledgements}

We are grateful for technical assistance from Russell McConnell on the Confocal Microscope and the Tufts GRASP Center for technical support (NIDDK grant P-30 DK 34928). We are also extremely grateful for samples of PSC833 from Novartis Pharma AG (Basel, Switzerland). This study was funded in part by the Tufts - New England Medical Center Hematology/ Oncology Fellowship (SA); LFM was a Leukemia and Lymphoma Society Fellow in the laboratory of John Coffin, whose continued guidance during the generation of this study is acknowledged and very much appreciated.

\section{References}

1. Stavrovskaya AA: Cellular mechanisms of multidrug resistance of tumor cells. Biochemistry 65: 95-106, 2000.

2. Lehnert M: Clinical multidrug resistance in cancer: a multifactorial problem. Eur J Cancer 32A: 912-920, 1996.

3. Beketic-Oreskovic L, Duran GE, Chen G, et al: Decreased mutation rate for cellular resistance to doxorubicin and suppression of MDR1 gene activation by the cyclosporin PSC 833. J Natl Cancer Inst 87: 1593-1602, 1995.

4. Scheper RJ, Broxterman HJ, Scheffer GL, et al: Overexpression of a M(r) 110,000 vesicular protein in non-P-glycoproteinmediated multidrug resistance. Cancer Res 53: 1475-1479, 1993.

5. Sognier MA, Zhang Y, Eberle RL, et al: Sequestration of doxorubicin in vesicles in a multidrug-resistant cell line (LZ-100). Biochem Pharmacol 48: 391-401, 1994.

6. Kawai H, Kiura K, Tabata M, et al: Characterization of nonsmall-cell lung cancer cell lines established before and after chemotherapy. Lung Cancer 35: 305-314, 2002.

7. Salinas AE and Wong MG: Glutathione S-transferases - a review. Curr Med Chem 6: 279-309, 1999.

8. Kuhl JS, Krajewski S, Duran GE, et al: Spontaneous overexpression of the long form of the bcl-x protein in a highly resistant P388 leukaemia. Br J Cancer 75: 268-274, 1997.

9. Tomida A, Naito M and Tsuruo T: Acute induction of adriamycinresistance in human colon carcinoma HT-29 cells exposed to a sublethal dose of adriamycin. Jpn J Cancer Res 86: 224-232, 1995.

10. Hahn SM, Russo A, Cook JA, et al: A multidrug-resistant breast cancer cell line induced by weekly exposure to doxorubicin. Int J Oncol 14: 273-279, 1999.

11. Slapak CA, Daniel JC and Levy SB: Sequential emergence of distinct resistance phenotypes in murine erythroleukemia cells under adriamycin selection: decreased anthracycline uptake precedes increased P-glycoprotein expression. Cancer Res 50: 7895-7901, 1990.

12. Fracasso PM, Slapak CA, Nair S, et al: Differential changes in genome structure and expression of the mdr gene family in multidrug-resistant murine erythroleukemia cell lines. Oncol Res 9: 183-191, 1997.

13. Modrak DE, Draper MP and Levy SB: Emergence of different mechanisms of resistance in the evolution of multidrug resistance in murine erythroleukemia cell lines. Biochem Pharmacol 54: 1297-1306, 1997.

14. Bhushan A, Slapak CA, Levy SB, et al: Expression of c-Fos precedes MDR3 in vincristine and adriamycin selected multidrug resistant mfurine erythroleukemia cells. Biochem Biophys Res Commun 226: 819-821, 1996.

15. Gerlier D and Thomasset N: Use of MTT colorimetric assay to measure cell activation. J Immunol Methods 94: 57-63, 1986.

16. Jiang XR, Kelsey SM, Wu YL, et al: Circumvention of Pglycoprotein-mediated drug resistance in human leukaemic cells by non-immunosuppressive cyclosporin D analogue, SDZ PSC 833. Br J Haematol 90: 375-383, 1995.

17. Lehne G and Rugstad HE: Cytotoxic effect of the cyclosporin PSC 833 in multidrug-resistant leukaemia cells with increased expression of P-glycoprotein. Br J Cancer 78: 593-600, 1998.

18. Lopes EC, Scolnik M, Alvarez E, et al: Modulator activity of PSC 833 and cyclosporin-A in vincristine and doxorubicinselected multidrug resistant murine leukemic cells. Leuk Res 25: $85-93,2001$

19. Watanabe T, Tsuge H, Oh-Hara T, et al: Comparative study on reversal efficacy of SDZ PSC 833, cyclosporin A and verapamil on multidrug resistance in vitro and in vivo. Acta Oncol 34: 235$241,1995$.

20. Bugg BY, Danks MK, Beck WT, et al: Expression of a mutant DNA topoisomerase II in CCRF-CEM human leukemic cells selected for resistance to teniposide. Proc Natl Acad Sci USA 88: 7654-7658, 1991. 
21. Slapak CA, Fracasso PM, Martell RL, et al: Overexpression of the multidrug resistance-associated protein (MRP) gene in vincristine but not doxorubicin-selected multidrug-resistant murine erythroleukemia cells. Cancer Res 54: 5607-5613, 1994.

22. Slapak CA, Lecerf JM, Daniel JC, et al: Energy-dependent accumulation of daunorubicin into subcellular compartments of human leukemia cells and cytoplasts. J Biol Chem 267: 10638-10644, 1992.

23. Hu XF, Slater A, Wall DM, et al: Cyclosporin A and PSC 833 prevent up-regulation of MDR1 expression by anthracyclines in a human multidrug-resistant cell line. Clin Cancer Res 2: 713-720, 1996.

24. Chen G, Duran GE, Steger KA, et al: Multidrug-resistant human sarcoma cells with a mutant P-glycoprotein, altered phenotype and resistance to cyclosporins. J Biol Chem 272: 5974-5982, 1997.

25. Futscher BW, Foley NE, Gleason-Guzman MC, et al: Verapamil suppresses the emergence of P-glycoprotein-mediated multidrug resistance. Int J Cancer 66: 520-525, 1996.

26. Deffie AM, Bosman DJ and Goldenberg GJ: Evidence for a mutant allele of the gene for DNA topoisomerase II in adriamycinresistant P388 murine leukemia cells. Cancer Res 49: 6879-6882, 1989.

27. Sullivan DM, Latham MD, Rowe TC, et al: Purification and characterization of an altered topoisomerase II from a drugresistant Chinese hamster ovary cell line. Biochemistry 28 : 5680-5687, 1989.

28. Zwelling LA, Hinds M, Chan D, et al: Characterization of an amsacrine-resistant line of human leukemia cells. Evidence for a drug-resistant form of topoisomerase II. J Biol Chem 264: 16411-16420, 1989.
29. Asano T, Nakamura K, Fujii H, et al: Altered expression of topoisomerase IIalpha contributes to cross-resistance to etoposide K562/MX2 cell line by aberrant methylation. Br J Cancer 92: 1486-1492, 2005.

30. Larsen AK and Skladanowski A: Cellular resistance to topoisomerase-targeted drugs: From drug uptake to cell death. Biochim Biophys Acta 1400: 257-274, 1998.

31. Mao Y, Yu C, Hsieh TS, et al: Mutations of human topoisomerase II alpha affecting multidrug resistance and sensitivity. Biochemistry 38: 10793-10800, 1999.

32. Chan VT, Ng SW, Eder JP et al: Molecular cloning and identification of a point mutation in the topoisomerase II cDNA from an etoposide-resistant Chinese hamster ovary cell line. J Biol Chem 268: 2160-2165, 1993.

33. Ritke MK, Allan WP, Fattman C, et al: Reduced phosphorylation of topoisomerase II in etoposide-resistant human leukemia K562 cells. Mol Pharmacol 46: 58-66, 1994.

34. Salvatore C, Camarda G, Naggi C, et al: NF-kappaß activation contributes to anthracycline resistance pathway in human ovarian carcinoma cell line A2780. Int J Oncol 27: 799-806, 2005.

35. Arlt A, Gehrz A, Muerkoster S, et al: Role of NF-kappaß and AKT/PI3k in the resistance of pancreatic carcinoma cell lines against gemcitabine-induced cell death. Oncogene 22: 3243-3251, 2003.

36. Nomura T, Yamasaki M, Nomura Y, et al: Expression of the inhibitors of apoptosis proteins in cisplatin-resistant prostate cancer cells. Oncol Rep 14: 993-997, 2005.

37. Yasui K, Mihara S, Zhao C, et al: Alteration in copy numbers of genes as a mechanism for acquired drug resistance. Cancer Res 64: 1403-1410, 2004.

38. Mirski SE, Bielawski JC and Cole SP: Identification of functional nuclear export sequences in human topoisomerase IIalpha and beta. Biochem Biophys Res Commun 306: 905-911, 2003. 